\title{
Impact on Soil Properties and Yield of Rainfed Groundnut Mono Cropping System (Arachis hypogae L.) under Long Term Application of Manure and Fertilizers
}

\author{
D. Salma*, K. Venkaiah and M.V.S. Naidu \\ Department of Soil Science \& Agricultural Chemistry, S. V. Agricultural College \\ Tirupati-517502, Andhra Pradesh, India \\ *Corresponding author
}

\begin{tabular}{|c|c|}
\hline & A B S T R A C T \\
\hline & \multirow{6}{*}{$\begin{array}{l}\text { Groundnut is the mostly grown commercial oilseed for millions of small scale farmers in } \\
\text { the semi-arid topics and under rainfed conditions in Andhra Pradesh. The productivity of } \\
\text { groundnut grown under rainfed situation is declining from the actual production of } 1.23 \mathrm{~m} \\
\text { t to the lowest yield of } 0.8 \mathrm{t} \mathrm{ta}^{-1} \text { in India, under the crop area coverage of } 1.38 \mathrm{~m} \text { ha. The } \\
\text { reasons behind the low productivity in India is mainly due to poor soil fertility, } \\
\text { deterioration of soil physical properties, monocropping, low rainfall and frequent } \\
\text { occurrence of dry spells, imbalanced use of plant nutrients and sub-optimal addition of } \\
\text { organic and inorganic fertilizers to soil. Application of manures and fertilizers change the } \\
\text { physical, chemical and biological properties of soil which in turn affects the availability of } \\
\text { soil nutrients. Long-term manure and fertilizers experiment provides valuable information } \\
\text { on impact of continuous use of fertilizers with varying combination of organics and } \\
\text { inorganics on soil physical, chemical properties and crop productivity and became good } \\
\text { platform for monitoring the changes in soil physical properties and productivity. Observed } \\
\text { effect of Long term application of inorganic fertilizer along with organic fertilizer changes } \\
\text { physical properties like infiltration rate, cumulative infiltration and aggregate MWD and } \\
\text { productivity. The literatures reported below regarding the long-term effect of application } \\
\text { of manure and fertilizers on Soil physical properties and yield of rainfed groundnut. }\end{array}$} \\
\hline Keywords & \\
\hline $\begin{array}{l}\text { Soil physical } \\
\text { properties, } \\
\text { Yield, } \\
\text { Groundnut mo } \\
\text { cropping syste }\end{array}$ & \\
\hline Article Info & \\
\hline & \\
\hline & \\
\hline
\end{tabular}

\section{Importance of long term effect of manure and fertilizers}

Long term field experiments are the primary source of scientific knowledge of changes that are taking place in soil physical, physicochemical and chemical properties over a long period of farming. Organic manures act not only as a source of nutrients and organic matter, but also increase size, biodiversity and activity of the microbial population in soil, influence structure, nutrients turnover and many other related physical, chemical and biological parameters of the soil.

Judicious use of organic manures such as FYM and Farm waste along with the chemical fertilizers improves by changing the soil 
physical, chemical and biological environmental properties which in turn affects the availability of soil nutrients improves the groundnut productivity (Singh, 2007). It is essential to identify such practices which bring more sustainability to the production system and create a good platform for monitoring the changes in soil physical properties besides improving the productivity. Long term application of inorganic fertilizer along with organic fertilizer changes physical properties like infiltration rate, cumulative infiltration and aggregate MWD and productivity (Brar et al., 2015).

\section{Physical characteristics of soils}

Soil physical environment has an important role in optimizing production with given resources of soil, water, energy and climate. Crop yields are affected more by physical conditions of soil than its nutrient status. The soil physical properties affect plant growth and thus are the indicators of soil quality for harnessing full potential of costly inputs like energy, fertilizer, crop varieties, irrigation etc. for long term sustainable agriculture. The long term persistence of cropping systems may lead to undesirable decline in soil physical environment.

\section{Soil texture}

Soil texture refers to the relative proportion of the various soil separates namely sand, silt and clay content present in the given soil mass. It determines the suitability of soils for growing different crops and nutrient supplying ability.

Majority of the groundnut growing soils of Chittoor district were sandy loam in texture and to some extent loamy sands (Munaswamy et al., 1989) (Ranganayakulu et al., 1986). While the texture of the groundnut growing soils of Nellore district and Yerpedu mandal of Chittoor district in Andhra Pradesh was loamy sand to sandy clay (Venkatesu et al., 2002). Chatterjee et al., (2005) reported that the groundnut growing alfisols of Dokhla in Maharashtra had clay loam in texture. Kuntal et al., (2008) observed that texture has not played any significant role in the variation of soil properties among the treatments. Leelavathi et al., (2009) reported that the texture of the groundnut grown soils in Yerpedu mandal of Chittoor district ranged from loamy sand to sandy clay loam. Impact of long term use of soil and nutrient management treatments imposed on red sandy loams was studied at All India Coordinated Research Project for Dryland agriculture, Ananthapur (Sharma et al., 2010).

\section{Soil porosity}

Soil porosity is influenced by the soil texture, soil structure, organic matter, depth and soil compaction. Observations indicated that long term application of FYM in combination with NPK resulted in increased porosity of vertisols Mahimairaja et al., (1986) and alfisols (Katile et al., 1992) similar observations were observed in a long-term experiment under maize-wheat cropping system, the pore space was more with FYM incorporation @ $20 \mathrm{t} \mathrm{ha}^{-1}$ followed by $100 \%$ NPK + FYM @ $10 \mathrm{t} \mathrm{ha}^{-1}$. This was mainly due to the lowering of bulk density while Prasad and Prasadini (2013) observed that at transplanting of rice by the substitution of $50 \%$ recommended level of $\mathrm{N}$ with FYM compared to continuous fertilizer application at recommended level in the kharif and rabi reason during both the years. This was obviously due to an increase in the volume of pore space because of the addition of organic matter to the total volume of the soil. Babar and Dongale (2013) reported that with respect to mustard crop the organic alone treatments contributed significantly to the enhanced porosity compared to control. This might be due to lowering of bulk density value of soil. 


\section{Bulk density}

Bulk density is influenced by soil texture, organic matter, compaction, nature of crops, management practices and tillage. Bulk density of the ideal soil is generally $1.33 \mathrm{Mg}$ $\mathrm{m}^{-3}$ whereas it may be $1.6 \mathrm{Mg} \mathrm{m}^{-3}$ for sandy soil. For coarse textured soil and fine textured soil, normally ranges from 1.40 to $1.75 \mathrm{Mg} \mathrm{m}$ ${ }^{3}$ and 1.10 to $1.40 \mathrm{Mg} \mathrm{m}^{-3}$, respectively.

Increase in organic matter lowers the bulk density of soil due to the continuous application of FYM has been reported by Sureshlal and Mathur (1989), Sheeba and Kumaraswamy (2001). However long term application of graded doses of NPK fertilizers did not show significant influence on bulk density but the combined application of organics (FYM@10 $\mathrm{t} \mathrm{ha}^{-1}$ ) and inorganics improved the physical condition of the soil by reducing the bulk density and while Similar trend was also reported by Bharadwaj and Omanwar (1992) Mahimairaja et al., (1986), Bellaki and Badanur (1997) under long-term experiment noticed that the bulk density of soil decreased significantly with the application of FYM or sunhemp either alone or in combination with fertilizers Arvind et al., (2004). Application of FYM @ $10 \mathrm{t} \mathrm{ha}^{-1}$ over a period of seven years continuously decreased the bulk density from 1.54 to 1.45 $\mathrm{Mg} \mathrm{m}^{-3}$ in sandy loams of Tirupati (Regional Agricultural Research Station, 2010).

Chandravanshi et al., (2001) reported that bulk density of alfisol decreased significantly with FYM plus lime in addition to NPK fertilizers in optimum dosage. Incorporation of organic manure viz., FYM and coir pith in the top layer prior to sowing did not influence the bulk density of lower layers of soil (Rajkannan et al., 2001). Sheeba and Kumaraswamy (2001) observed a significant decrease in bulk density with increase in organic matter content. Bhagat et al., (2003) reported that bilk density values were decreased at all levels of lantana incorporation to soil as compared to control due to increased total porosity. Selvi et al., (2003) observed that application of inorganic fertilizers over a period of 26 years increased the bulk density of inceptisols significantly in finger milletcowpea cropping system.

Application of FYM @ $10 \mathrm{tha}^{-1}$ over a period of seven years continuously decreased the bulk density from 1.54 to $1.45 \mathrm{Mg} \mathrm{m}^{-3}$ in sandy loams of Tirupati (Regional Agricultural Research Station, 2010). Verma et al., (2010) reported that lowest bulk density was recorded with FYM incorporation@20 t $\mathrm{ha}^{-1}$ followed by $100 \%$ NPK+FYM @ $10 \mathrm{t}$ $\mathrm{ha}^{-1}$. The lowering of bulk density might be due to increase in water stable aggregates and higher organic carbon which resulted in more space and good soil aggregation. Shahid et al., (2013) reported that the range of bulk density from 1.40 in NPK+FYM plot to $1.54 \mathrm{Mg} \mathrm{m}^{-3}$ in the control with no added fertilizer. Reduction of bulk density in plots with continuous application of NPK along with FYM might be due to the increase in soil organic carbon. Yaduvanshi et al., (2013) noticed that the use of organic manures (FYM or GM) with inorganic fertilizers significantly improved the bulk density of the $0-15 \mathrm{~cm}$ soil layer over inorganic fertilizers treatments. Under long-term fertilization and manuring on groundnut crop, lowest bulk density was observed under $5 \mathrm{Mg} \mathrm{ha}^{-1} \mathrm{FYM}$ and highest in $100 \%$ recommended dose of fertilizers (Srinivasarao et al., 2013). Nagar et al., (2016) reported that long term application of organic manures and crop residue exerted significant reduction in bulk density. The lowest bulk density has been noticed with combine application of FYM + phosphocompost (1.29 $\mathrm{Mg} \mathrm{m}^{-3}$ ) followed by $\left(1.29 \mathrm{Mg} \mathrm{m}^{-3}\right)$ pigeonpea stalk + phosphocompost over $\left(1.34 \mathrm{Mg} \mathrm{m}^{-3}\right)$ recommended dose of fertilizers alone. 


\section{Hydraulic conductivity}

It is the rate of flow of liquid through a porous medium under unit hydraulic gradient. It is influenced by the soil texture, structure, compaction, organic matter and fluidity. Greater organic matter and coarser, more is the hydraulic conductivity of the soil.

Nambiar (1994) reported that addition of FYM in combination with NPK fertilizers improved the water movement in fine textured soils due to formation of larger water stable aggregates while it was reduced in coarse textured soils due to reduction in non-capillary porosity, thereby moderating both the adverse soil conditions. However, An increase in hydraulic conductivity by the addition of organic manures was also observed by Vennila and Muthuvel (1998) who noticed that the increase in hydraulic conductivity of soils of the plough layer was associated with the buildup of organic matter. Leroy et al., (2008), noticed that saturated hydraulic conductivity under integrated use of NPK and FYM was 21.4\% higher than sole use of NPK and 95.8\% higher than the control treatment. Bandyopadhyay et al., (2010) noticed that saturated hydraulic conductivity under integrated use of NPK and FYM was $21.4 \%$ higher than sole use of NPK and $95.8 \%$ higher than the control treatment. Upadhayay et al., (2013) noticed that the treatments involving incorporation of organic matter and residue recycling, improved the soil physical conditions by increasing in-situ infiltration rate, hydraulic conductivity, porosity and decreasing particle/ bulk density in all the cropping systems. Sharma (2014) observed that continuous application of organic alone or in combination with inorganic fertilizer significantly increased the hydraulic conductivity of the soil. The increase in hydraulic conductivity might be due to addition of organic matter which in turn increased porosity of soil.

\section{Infiltration rate}

Infiltration is the entry of water at the soil air interface due to sorption and vertical flow through the soil profile. The process is of great practical importance as it determines how much of rain water or irrigation water enters the soil and overflows the land surface as runoff.

Chawla and Chhabra (1991) reported that long term application of inorganic fertilizers to sodic soil improved the water permeability compared to the control and also observed the application of $\mathrm{P}$ along with $\mathrm{N}$ further increased the infiltration rate under rice-wheat crop sequence. Prasad and Prasadini (2013) indicated that there was a distinct response of significant improvement in infiltration of water at transplanting due to substitution of 25 or $50 \%$ recommended level of $\mathrm{N}$ with FYM compared to the practice of recommended level of fertilizer application both in kharif and rabi season during the two years. Brar et al., (2015) reported that the value of infiltration rate increased by $16.1 \%$ when application of NPK was increased from $50 \%$ to $100 \%$ of the recommended rate. The highest infiltration rate was observed in 100\% NPK + FYM treatment where more stable aggregation and higher soil organic matter concentrations were measured. The increase in infiltration rate might be due to increase in micropores and macropores in the soil resulting from better aggregation by cementing of soil particles together due to higher soil organic matter and favorable living conditions for soil organisms.

\section{Water holding capacity of the soil}

It is the average soil water content (expressed in percentage on oven dry weight basis) of a disturbed soil sample of $1.0 \mathrm{~cm}$ high which is at equilibrium with a water table at its lower surface, which depends on texture, the amount and nature of organic and inorganic colloidal material. 
Muthuvel et al., (1982) observed the positive relationship between clay content of soil and water holding capacity in the permanent manurial experiment at Coimbatore. Parameswar et al., (1989) stated that due to continuous incorporation of FYM along with 100 per cent NPK to sandy clay loam soil at Hyderabad, maximum water holding capacity of the soil was increased. This might be attributed to improvement in structure, as evident from the decrease in bulk density, increase in soil structural indices and organic carbon content of the soil. Bhriguvanshi (1998) found that combined application of FYM along with $\mathrm{N}$ fertilizer increased water holding capacity of the soil. It was mainly attributed to the improvement in soil structural indices. Bhagat et al., (2003) reported the maximum water retention with lantana incorporation@30 Mg ha ${ }^{-1}$ and minimum under no lantana incorporation. Pernes and Tessier (2004) observed that continuous application of organic matter over a period of 70 years increased water retention at high water potential in soils of versailles in France. Bhattacharayya et al., (2004) observed the maximum soil water retention in the $\mathrm{NPK}+\mathrm{FYM}$ treatment in rainfed system. The inclusion of $\mathrm{P}$ and FYM in the above said treatment might be attributed to the improvement of aggregates and favourable pore geometry in the soil. Sarawad et al., (2005) observed that the infiltration rate, water stable aggregates, porosity, hydraulic conductivity and maximum water holding capacity of the soil increased considerably with sunhemp incorporation or compost application. The improvement in soil physical properties could be due to increased organic matter content of the soils, which inturn improved soil structure.

Prasad and Prasadini (2013) reported that the water retention of the soil improved significantly by substituting 25 or $50 \%$ recommended level of $\mathrm{N}$ with FYM. The water holding capacity relatively low at 15-30 $\mathrm{cm}$ than $0-15 \mathrm{~cm}$ soil depth irrespective of the treatment during both the years. Tadesse et al., (2013) reported that application of $15 \mathrm{t} \cdot \mathrm{ha}^{-1}$ FYM increased available water holding capacity by $17.6 \%$, while it reduced the soil bulk density by $0.31 \mathrm{~g} \mathrm{~cm}^{-3}$. Dubey and Datt (2014) noticed that the maximum water holding capacity was recorded in organic treatment. Organic matter content which resulted in the improvement in stable soil aggregates and macro and micro pores spaces caused to increased in free movement of water within the soil might have resulted to increase in water holding capacity of the soil. Gabhane et al., (2014) reported that among long-term integrated nutrient management treatments, significantly highest water holding capacity was noticed in treatment of $50 \%$ recommended dose of fertilizers along with FYM @ $15 \mathrm{t} \mathrm{ha}^{-1}$ which was superior over rest of the treatments. Parewa et al., (2014) noticed that in integrated treatment of $100 \%$ NPK fertilizer levels and FYM gave numerically more water holding capacity values as compared to control and 100\% NPK fertilizers applied treatments.

\section{Water aggregates stability}

An aggregate may be defined as a naturally occurring cluster or group of two or more primary soil particles stabilized by organic matter, iron and aluminium oxides, carbonates and or silica in which particles cohere to each other strongly than to surrounding particles. The size distribution of soil aggregates thus determines the pore size distribution of soil and has a bearing on the erodibility of the surface soil by wind and water.

Mishra and Sharma (1997) noticed that continuous application of full dose NPK $(100 \%)$ showed significant increase both in the fine as well as the coarser aggregates over the half NPK and unfertilized treatments. 
Karche et al., (2013) observed the MWD increased from $0.62 \mathrm{~mm}$ (control) to $0.68 \mathrm{~mm}$ (chemical fertilizers alone) and further to 0.72 $\mathrm{mm}$ (integrated nutrient management) under long-term experiment indicating profund influence of organics on soil structure.

Gathala et al., (2007) noticed that the integrated use of FYM and chemical fertilizer increased the water stable aggregates after harvesting stage of wheat, which could be attributed to the beneficial effects of certain polysaccharides formed during decomposition of organic residues by microbial activity as well as cementing action of bacteria and fungi. Verma et al., (2010) showed that the maximum water stable aggregates were recorded under $20 \mathrm{t} \mathrm{FYM} \mathrm{ha}^{-1}$ treatment and $100 \% \mathrm{NPK}+10$ t FYM ha $^{-1}$ significantly increased the soil aggregation over $100 \%$ NPK.

\section{Physico-chemical properties}

\section{Soil pH}

Soil reaction is an indication of soil acidity or basicity. $\mathrm{pH}$ is the negative logarithm (base 10) of the activity of $\mathrm{H}^{+}$in the soil solution. Soil $\mathrm{pH}$ affects the root growth, crop nutrition and yield production by influencing the availability of nutrients, toxic substances, microbial activity and other soil processes. It is influenced by nature of soil colloids.

By continuous application of inorganic fertilizers showed slight increase in soil $\mathrm{pH}$ with increasing soil depth Singh et al., (2007) similar findings were recorded by Stalin et al., (2006) with application of organic and inorganic fertilizers in a long-term fertility experiment conducted for a period of 10 years in Cauvery delta of Tamil Nadu. While continuous incorporation of organic manures and crop residues like green manure/ farmyard manure/ rice-straw alone over a period of 8 years results in significant reduction of the soil pH Gupta et al., (2008). The increase in soil pH by 1.0 unit might be due to ameliorative effect of lime on soil acidity. While, drastic fall in soil $\mathrm{pH}$ might be due to continuous application of inorganic fertilizers alone. Urkurkar et al., (2010) reported that $\mathrm{pH}$ slightly decreased due to continuous application of green manure/ farmyard manure/rice-straw residue compared to inorganic fertilizers alone. Hemalatha and Chellamuthu (2013) stated that even though there was no significant change in $\mathrm{pH}$ of the soil among the treatments, there was a non significant reduction in $\mathrm{pH}$ of the soil treated with 100 per cent NPK + FYM. This reduction might be attributed to the release of organic acids produced during the decomposition of organic matter from the FYM. Kumari et al., (2013) reported that the continuous application of $100 \%$ N, $100 \%$ NP and $100 \%$ NPK significantly decreased the $\mathrm{pH}$, while application of FYM alone or $100 \%$ NPK with lime recorded significantly higher $\mathrm{pH}$ over control.

Punjab, Agricultural University, Ludhiana. Decline in $\mathrm{pH}$ might have resulted from buildup of organic matter over a period of 36 years in manure and fertilizer treated plots. It was also noticed that the $\mathrm{pH}$ was significantly reduced with $150 \%$ NPK application as compared to 50\% NPK Kumara et al., (2014) showed that decrease in $\mathrm{pH}$ was more with the addition of FYM compared to poultry manure and pressmud. Highest soil $\mathrm{pH}$ (7.87) was observed in plots where only NP fertilizers were applied. It might be due to the leaching of soluble salts from surface soil. Brar et al., (2015) reported that the soil $\mathrm{pH}$ was decreased with application of different combinations of manure and fertilizers in maize-wheat rotation under long-term experiment conducted at treatment and 36 years of application of FYM showed no significant changes in soil $\mathrm{pH}$. 


\section{Electrical conductivity (EC)}

The major sources of salts to the soil are through irrigation water. The measurement of electrical conductivity gives the concentration of soluble salts in the soil at a particular temperature. This is useful to know the salts accumulation in soil which are detrimental to plant growth at higher levels.

Bhaskara Reddy et al., (1992) reported that EC of the soil did not change over a period of ten years of continuous manuring and fertilization to rainfed groundnut crop in alfisols. Balaguravaiah et al., (2005) indicated highest EC in half recommended fertilizer dose and FYM in a long-term fertilizer experiment over a period of 18 years at Anantapur. Stalin et al., (2006) reported that EC was increased slightly when the organic and inorganic fertilizers applied for ten years continuously. This might be due to the dissolved salts contributed from soil and the release of ionic species in the reduction process similar findings was reported by Brar et al., (2014).

\section{Organic carbon}

Organic carbon content of soil is an indicator of soil productivity and fertility. It can greatly improve the physical and chemical properties of soil. Availability of nutrients from organic matter is governed by several factors viz., ion exchange reactions, chelation, buffering capacity, enzyme activity and microbial activity etc.

Balaguravaiah et al., (2005) reported the significant increase in organic carbon from 0.48 to 0.52 per cent by the application of NPK fertilizers along with FYM in a long term fertilizer experiment in vertisols of Bellary similar finding was done at different depths of soil and results revealed that oxidisable soil organic carbon content was maximum in NPK+FYM treatment at $0-15 \mathrm{~cm}$ depth due to root biomass accumulation over a period of 29 years while the non-oxidisable soil organic carbon content was highest at 15$30 \mathrm{~cm}$ depth. Hati et al., (2006) reported that in Indian soils the organic carbon under unfertilized and $\mathrm{N}$-fertilized plots was similar to the initial level after 31 years, which might be due to its low initial level of soil organic carbon and also because of crop roots being retained in the soil have replenished the loss of soil organic carbon. Behera et al., (2009) reported that continuous cropping and fertilization for 31 years in Typic Haplustepts of Indian Agricultural Research Institute in New Delhi resulted in decrease of organic carbon content by 0.06 per cent from initial value in control. Singh et al., (2011) revealed that soil organic carbon content in soil at crop harvest was significantly increased due to integrated application of biofertilizers and FYM as compared to chemical fertilizer alone.

\section{Chemical properties}

\section{Available nitrogen}

The soil available nitrogen along with fertilizer nitrogen plays a vital role in plant nutrition. The Indian soils had low in nitrogen because of tropical climate.

Gupta et al., (2008) reported that continuous application of crop residues along with FYM and green manure significantly increased the available $\mathrm{N}$ of soil over 100 per cent NPK alone treatment. Stalin et al., (2006) observed that continuous application of NPK+ green manure + gypsum recorded highest available $\mathrm{N}$ compared to other treatments in long term fertilizer experiment. Prasad et al., (2010) reported that continuous application of crop residues along with $\mathrm{Zn}$ significantly enhanced the available Sutaria et al., (2011) reported that available $\mathrm{N}, \mathrm{P}$ and $\mathrm{K}$ significantly improved with continuous application of RDF + enriched compost @ 6 t ha $^{-1}$. Shirale (2014) observed highest buildup of available $\mathrm{N}$ by the 
treatment receiving 100 per cent NPK + FYM@ $10 \mathrm{Mg} \mathrm{ha}^{-1}$ followed by 150 per cent NPK.

\section{Available phosphorus}

Phosphorus is one of the essential nutrients for plant growth. It is a vital component of the substances that are building blocks of genes and chromosomes. The total P-content in Indian soils ranges from 100 to $2000 \mathrm{ppm}$ (Tandon, 1989). The total $\mathrm{P}$ is poorly correlated with available $\mathrm{P}$ in soils and therefore total $\mathrm{P}$ is rarely used to describe soils P-fertility status.

Acharya et al., (1988) revealed that long-term application of farm yard manure in combination with 100 per cent NPK increased phosphorus content in the surface and subsurface soil layers to an extent of 41 per cent. Babhulkar et al., (2000) noticed that long-term application of FYM and fertilizers in black soil significantly increased available Selvi et al., (2003) reported that continuous application of $\mathrm{P}$ fertilizers in combination with $\mathrm{N}$ and $\mathrm{K}$ significantly increased available $\mathrm{P}_{2} \mathrm{O}_{5}$ content of the soil over $\mathrm{P}$ alone treatment. Balaguravaiah et al., (2005) reported that $\mathrm{P}$ availability was increased by 2.5 to 2.9 times over initial level with the continuous use of inorganic fertilizers over a period of 18 years in treatment where phosphorus was applied @ $17.5 \mathrm{~kg} \mathrm{ha}^{-1}$ in groundnut crop. Stalin et al., (2006) observed that the available P content was increased as compared to the initial available $\mathrm{P}$ status with continuous application of 100 per cent NPK alone or with organics. Behera et al., (2009) noticed that the highest $\mathrm{P}$ was recorded under 100 per cent NPK+FYM treated plot. This was due to the cumulative residual effect of applied phosphate fertilizers over a period of 31 years. Rajani et al., (2010) reported that available $\mathrm{P}$ significantly improved with the use of $100 \%$ recommended fertilizer + FYM in long term experiment soils. Srinivasarao et al., (2013) observed a large buildup of available $\mathrm{P}$ in soil received the fertilizer and manurial treatments under long-term experiment on groundnut crop. Dotaniya et al., (2014) revealed that available $\mathrm{P}$ in soil solution increased with higher levels of organic residue as well as increasing incubation time which converted non-labile $\mathrm{P}$ into labile $\mathrm{P}$.

\section{Available potassium}

Potassium is one of the three major plant nutrient elements. Its importance in Indian agriculture has increased with cropping intensity. Potassium plays vital roles in enzyme activation, water relations (Osmotic regulation etc.), energy relations, translocation of assimilates, photosynthesis, protein and starch synthesis.

Tiwari et al., (2002) reported that declined status of available $\mathrm{K}$ due to intensive cropping over the years. The maximum decline was observed in control and 100 per cent $\mathrm{N}$ treatment. Ravankar et al., (2004) concluded that application of FYM alone significantly decreased the available potassium content of the soil compared to the application of FYM in combination with inorganic fertilizers in a long term experiment. Balaguravaiah et al., (2005) reported that the $\mathrm{K}$ availability was higher in FYM applied or conjunctive use of FYM with the chemical fertilizer treatments in alfisols in a long term fertilizer experimental soils. Gupta et al., (2008) found that the crop residue incorporation along with 100 per cent NPK for 8 years increased the available $K$ status by 10.6 per cent over its initial status of $123 \mathrm{~kg} \mathrm{ha}^{-1}$ in loamy sand soils. Singh et al., (2009) observed that available $\mathrm{K}$ increased significantly with NPK and lime application but combined application of FYM + PK did not influence $\mathrm{K}$ availability in soil. Bharose et al., (2014) depicted that available N, P, K, of soil was found in treatment receiving $55 \mathrm{~kg}$ Sulphur + FYM 10t ha ${ }^{-1}$ and minimum was found in control treatment. 
Effect of long term application of organic and inorganic fertilizers on yield and yield attributes

Balaguravaiah et al., (2005) reported that the highest pod yield was obtained by the half of recommended dose of fertilizers + FYM @ $4 \mathrm{t}$ $\mathrm{ha}^{-1}$. Prabakaran (2006) reported that tomato yield was increased due to incorporation of organic carbon which might have improved the physical, chemical, biological properties and better solubilization of nutrients. Yeledhalli et al., (2007) reported that the pod yield of groundnut increased significantly by the application of $\mathrm{K}$ and $\mathrm{Ca}$ in the ratio of 1.5:1 i.e., $75 \mathrm{~kg} \mathrm{~K} \mathrm{ha}^{-1}$ and $50 \mathrm{~kg} \mathrm{Ca} \mathrm{ha}^{-1}$ over absolute control and recommended dose of $\mathrm{NPK}+500 \mathrm{~kg}_{\text {gypsum ha }}{ }^{-1}$ at $30 \mathrm{DAS}$ in sandy clay loams of Raichur in Karnataka. Kanu et al., (2008) observed that the application of Phosphate rich organic manure made of double recommended dose of $\mathrm{P}_{2} \mathrm{O}_{5}$ through Phosphate rock and FYM in 1:4 ratio significantly increased the pod and haulm yield of groundnut.

Sharma et al., (2010) observed that among the nutrient treatments, groundnut sole 100\% organic treatment (SQI 2.62) proved quit superior in improving the soil quality followed by conjuctive nutrient application viz., $50 \%$ organic $50 \%$ inorganic (SQI 2.35). Sharma et al., (2011) revealed that application of $\mathrm{N}, \mathrm{P}, \mathrm{K}, \mathrm{S}$ and $\mathrm{Zn}$ significantly enhanced the pod and haulm yields of groundnut by 25.9 and 2.4 per cent over 100 per cent NPK. Srinivasa et al., (2012) reported that the application of organics in the form of FYM/groundnut shell along with chemical fertilizer significantly improved SYI of groundnut compared to use of recommended rate of NPK. Probably it might be due to a high moisture retention capacity in organic manure treated plots as well as better nutrient supply by the integrated nutrient management treatment.
Kumari et al., (2013) concluded that continuous application of $100 \%$ NPK along with lime, FYM and integrated management practices were beneficial for restoration of soil organic carbon, maintaining soil fertility and yield sustainability of maize-wheat cropping system in alfisol. Parvathi et al., (2013) showed that application of NPK + gypsum $+\mathrm{ZnSO}_{4}$ recorded highest pod yield of $1499 \mathrm{~kg} \mathrm{ha}^{-1}$ which was on par with NPK + gypsum and FYM alone treated plot in long term fertilizer experiment in alfisols of Tirupati. Tadesse et al., (2013) concluded that combined application of $15 \mathrm{tha}^{-1}$ FYM, 120 $\mathrm{kg} \mathrm{ha}^{-1} \mathrm{~N}$ and $100 \mathrm{~kg} \mathrm{ha}^{-1} \mathrm{P}_{2} \mathrm{O}_{5}$ resulted in improvement of most soil physical, physicochemical properties and nutrient balances that might lead to increased and sustained production of rainfed rice in plains of northwestern Ethiopia.

Gabhane et al., (2014) showed that integrated application of FYM @ $10 \mathrm{t} \mathrm{ha}^{-1}$ along with $50 \%$ recommended dose of fertilizers through chemical fertilizers was beneficial in improving soil quality index and sustaining the cotton productivity in rainfed vertisols under semiarid region of Maharashtra. Sharma et al., (2014) observed the significant linear relationships between soil quality indices (physical, physico-chemical, chemical properties) and crop yield (sorghum and castor). Shirale et al., (2014) reported that application of NPK+FYM under SoyabeanSafflower system was significantly superior over rest of the treatments in respect of grain yield, yield equivalent, $\mathrm{B}: \mathrm{C}$ ratio and buildup of soil fertility. Brar et al., (2015) observed that the long term effect of inorganic fertilizer along with organic fertilizer $(100 \%$ NPK + FYM) had resulted in maximum infiltration rate, cumulative infiltration and aggregate MWD. Improved soil physical conditions and increase in soil organic matter might have resulted in higher maize and wheat yields. 


\section{References}

Acharya, C. L., Bhishnoi, S. K and Yadhuvanshi, H. S. 1988. Effect of long term application of fertilizers and organic and inorganic amendments under continuous cropping on soil physical and chemical properties. Indian Journal of Agricultural Science. 58(7): 507-516.

Annual Reports, Regional Agricultural Research Station, Tirupati. 2010. Acharya N.G Ranga Agricultural University, Hyderabad.

Arvind Verma and Kanthaliya, P. C. 2004. Effect of long term manuring and fertilization on soil organic carbon, bulk density and Azatobacter population of inceptisol in maize-wheat cropping sequence. International symposium on 'organic farming and renewable sources of sustainable agriculture':

Babar, S and Dongale, J.H. 2013. Effect of organic and inorganic fertilizers on soil fertility and crop productivity under mustard-cowpea-rice cropping sequence on lateritic soil of Konkan. Journal of the Indian Society of Soil Science. 61(1): 7-14.

Babhulkar, P.S., Wandile, R.M., Badole, W.P and Balpande, S.S. 2000. Residual effect of long term application of FYM and fertilizers on soil properties (vertisol) and yield of soybean. Journal of the Indian Society of Soil Science. 48(1): 89-92.

Balaguravaiah, D., Adinarayana, G., Prathap, $S$ and Yellamanda Reddy, T. 2005. Influence of long term use of inorganic and organic manures on soil fertility and sustainable productivity of rainfed groundnut in Alfisols. Journal of the Indian Society of Soil Science. 53(4):608-611.

Bandyopadhyay, K.K., Misra, A.K., Ghosh, P.K and Hati, K.M. 2010. Effect of integrated use of farmyard manure and chemical fertilizers on soil physical properties and productivity of soyabean. Soil \& Tillage research.110: 115-125.

Behera, S. K and Dhyan Singh. 2009. Effect of 31 years of continuous cropping and fertilizer use on soil properties and uptake of micronutrients by maize (Zea mays) - wheat (Triticum aestivum) System. Indian Journal of Agricultural Sciences. 79 (4): 264-267.

Bellakki, M. A and Badanur, V. P. 1997. Long term effect of integrated nutrient management on properties of vertisol under dryland agriculture. Journal of the Indian Society of Soil Science. 45(3): 438- 442.

Bhagat, R.M., Bharadwaj, A.K and Sharma, P.K. 2003. Long term effect of residue management on soil physical properties, water use and yield of rice in north western India. Journal of the Indian Society of Soil Science. 51(2): 111-117.

Bharadwaj, V., Omanwar, P. K., Sharma, R.A and Viswanath. 1992. Long term effects of continuous rotational cropping and fertilizers on crop yields and soil properties-I. Effects on crop yields and nutrient uptake. Journal of the Indian Society of Soil Science. 42: 247-253.

Bharose, R., Thomas, T., Singh, S.K., Bairwa, J.P and Singh, D. 2014. Effect of Sulphur and Farm Yard Manure on physical and chemical properties of Sunflower grown soil and nutrient uptake by crop. Bulletin of Environmental and Scientific Research. 3(1): 1-7.

Bhaskara Reddy, N., Ranganayakulu, C., Seshagiri Rao, M., Raja Reddy, C. K., Srinivasa Reddy, C. K and Venkaiah, K. 1992. Long term effects of manure and fertilizers on composition and uptake of nutrients by rainfed groundnut (Arachis hypogaea L.) with reference to yield, nitrogen, phosphorus and potassium. 
New Botanist. XIX: 169-175.

Bhattacharyya, R., Kundu, V.P.S., Srivastva, A.K and Gupta, H.S. 2004. Effect of long-term of manuring on soil organic carbon, bulk density and water retention characteristics under soybean-wheat cropping sequence in north-western himalayas. Journal of the Indian Society of Soil Science. 52 (3): 238-242.

Brar, B.S., Singh, J., Singh, G and Kaur, G. 2015. Effects of long term application of inorganic and organic fertilizers on soil organic carbon and physical properties in maize-wheat rotation. Agronomy. 5(2):220-238.

Chandravanshi, P., Sudhir K., Srikanth K and Badrinath. 2001. Red soil Characterisation under permanent fertilizer and cropping schedule at Banglore. Physical methods of soil characterization. (Ed by Behari J). Narosa Publishing house, New Delhi, India. 171-176.

Chatterjee, A., Dosani, A.A.K., Talashikar, S.C and Mehta, V.B. 2005. Effect of lime on yield, quality and nutrient uptake by six groundnut varieties and properties of an alfisol. Journal of the Indian Society of Soil Science. 53(1): 128-132.

Chawla, K. L and Chhabra, R. 1991. Physical properties of gypsum amended sodic soils as affected by long term use of fertilizers. Journal of the Indian Society of Soil Science. 39: 40-46.

Dotaniya, M.L., Datta, S.C., Biswas, D.R and kumar, K. 2014. Effect of organic sources on phosphorus fractions and available phosphorus in typic haplustept. Journal of the Indian Society of Soil Science. 62 (1): 80-83.

Dubey, Y.P and Datt, N. 2014. Influence of organic, inorganic and integrated use of nutrients on productivity and quality of pea (Pisum sativum) vis-à-vis soil properties. Indian Journal of
Agricultural Sciences. 84(10): 11951200.

Gabhane, V.V., Sonune, B.A and Katkar, R.N. 2014. Long term effect of tillage and integrated nutrient management on soil quality and productivity of rainfed cotton in vertisols under semi-arid conditions of Maharashtra. Indian Journal Dryland Agriculture Research \& Development. 29(2): 71-77.

Gathala, M.K., Kanthaliya, P.C., Verma, A and Chahar, M.S. 2007. Effect of integrated nutrient management on soil properties and humus fractions in the long-term fertilizer experiments. Journal of the Indian Society of Soil Science. 55(3): 360- 363.

Gupta, B.K.R.K and Bhandari, A.L. 2008. Soil fertility changes after long term application of organic manures and crop residues under ricewheat system. Journal of the Indian Society of Soil Science. 56(1): 80-85.

Hati, K. M., Swarup, A., Singh, D., Mishra, A. K. Ghosh, P. K. 2006. Long term continuous cropping, fertilization and manuring effects on physical properties and organic carbon content of a sandy loam soil. Australian Journal of Soil Research. 44:487-495.

Hemalatha, S and Chellamuthu, S. 2011. Effect of long term fertilization on phosphorus fractions under finger millet-maize cropping sequence. Madras Agricultural Journal. 98 (12): 344-346.

Kanu Murmu, Ch., Pulla Rao, Chandrasekhar, K., Veeraraghavaiah, $\mathrm{R}$ and Venkateswarulu, B. 2008. Effect of phosphate Rock Enriched FYM on growth and yield of groundnut (Arachis hypogaea L.). The AndhraAgricultural Journal. 55(1):1-5.

Karache, V.K., Patil, S.R., Kulkarni, A.A., Patil, V.S and Katkar, R.N. 2013. Longterm integrated nutrient management for 
enhancing soil quality and crop productivity under intensive cropping system on vertisols. Journal of the Indian Society of Soil Science. 61(4): 323-332.

Katile, P., Leinweber, $\mathrm{P}$ and Menning, P. 1992. On the influence of soil organic matter on physical properties of soil. Agrobiological Research. 45: 18-27.

Kumara, B.H., Antil, R.S and Raj, D. 2014. Impact of long term manures and fertilizers application on carbon sequestration and its efficiency under pearlmillet-wheat cropping sequence. International Journal of Farm Sciences. 4(1): 21-26.

Kumari, G., Thakur, S.K., Kumar, $\mathrm{N}$ and Mishra, B. 2013. Long term effect of fertilizer, manure and lime on yield sustainability and soil organic carbon status under maize (Zea mays)-wheat (Triticum aestivum) cropping system in alfisols. Indian Journal of Agronomy. 58 (2):152-158.

Kuntal, M.H., Swarup, A., Mishra, B., Manna, M.C., Wanjari, R.H., Mandal, K.G and Misra, A.K. 2008. Impact of long-term application of fertilizer, manure and lime under intensive cropping on physical properties and organic carbon content of an alfisol. Geoderma. 148: 173-179.

Leelavathi, G.P., Naidu, M.V.S., Ramavatharam, $\mathrm{N}$ and Sagar, G.K. 2009. Studies on genesis, classification and evaluation of soils for sustainable land use planning in Yerpedu mandal of Chittoor district, Andhra Pradesh. Journal of the Indian Society of Soil Science. 57(2): 109-120.

Leroy, M., Herath, H.M.S., Sleutel, S., Deneve, S., Gabriels, D., Reheul, D and Moens, R. 2008. The quality of exogeneous organic matter, short term effects on soil physical properties and soil organic matter fraction. Land use and Management. 24: 139-147.

Mahimairaja, S., Helkiah, J and Gopalaswamy, A. 1986. Long term effect of graded doses of fertilizers and manures on soil physical conditions. Madras Agricultural Journal. 73: 340347.

Mishra, V.K and Sharma, R.B. 1997. Effect of fertilizers alone and in combination with manure on physical properties and productivity of entisol under rice-based cropping systems. Journal of the Indian Society of Soil Science. 45(1): 84-88.

Munaswamy, V., Subba Rao, I. V and Rajendra Prasad, B. 1989. A study on nutrient status of groundnut growing soils of Chittoor district. The Andhra Agricultural Journal. 36:287-291.

Muthuvel, P., Kandaswamy, P and Krishnamoorthy, K. K. 1982. Effect of long term fertilization on the water holding capacity, bulk density and porosity of soils. Madras Agricultural Journal. 69(9): 614-617.

Nagar, R.K., Goud, V.V., Kumar, R and Kumar, R. 2016. Effect of organic manures and crop residue management on physical, chemical and biological properties of soil under pigeonpea based intercropping system. International Journal of Farm Sciences. 6(1): 101113.

Nambiar, K.K.M and Abrol, I.P.1989.Long term fertilizer experiments in India. Fertilizers News. 34(4): 11-20.

Parameswar, M., Shantaiah, V., Rao, M.S., Rao, A.P and Rao P.N. 1989. Effect of long term fertilization under intensive cropping on some soil physical properties and rice yield. Andhra Agricultural Journal. 36(2): 152-156.

Parewa, H.P., Yadav, J and Rakshit, A. 2014. Effect of fertilizer levels, FYM and Bioinoculants on soil properties in inceptisol of Varanasi, Uttar Pradesh, India. International Journal of 
Agriculture, Environment \& Biotechnology. 7(3): 517-525.

Parvathi, E. 2013. Long term effect of manure and fertilizers on the physical and chemical properties of an alfisol under semi arid rainfed conditions. M.Sc. (Ag). Thesis. Acharya N.G Ranga Agricultural University, Hyderabad, India.

Pernes A-DeBuyser and Tessier, D. 2004. Soil physical properties affected by long term fertilization. European Journal of Soil Science. 55: 505 - 512.

Prabakaran, C. 2006. Impact of some organic ' $\mathrm{N}$ ' sources on soil physical properties and yield of tomato. Madras Agricultural Journal. 93 (1- 6): 46 - 52.

Prasad, M.V and Prasadini, P. P. 2013. Influence of integrated nutrient management on physical properties of alfisols under rice-rice cropping system in southern Telangana zone. 2013. Journal of Research, ANGRAU. 41(1): 20-29.

Prasad, R.K., Vipinkumar, Prasad, B and Singh, A.P. 2010. Long-term effect of crop residues and zinc fertilizer on crop yield, nutrient uptake and fertility buildup under rice-wheat cropping system in Calciorthents. Journal of The Indian Society of Soil Science. 58(2): 205-211.

Rajani, A.V., Patil, D.V., Shobhana, H.K., Naria, J.N and Golakiya, B.A. 2010. Dynamics of phosphorus fractions in a calcareous vertic haplusteps under AICRP-LTFE soils. An Asian Journal of soil science. 5 (1): 83-89.

Rajkannan., Balasundaram, C.S., Basker, A and Selvi, D. 2001. Residual effect of tillage systems coupled with organics on soil physical properties after groundnut (Var CO2) in a sandy clay loam having subsoil hard pan. Madras Agricultural Journal. 88 (1-3): 63-69.

Ranganayakulu, C., Prasad Rao, D. M. V., Padma Raju, A., Sreenivasa Moorthy,
V. V. M., Prabhu, M. R. L and Sankara Reddi, G. H. 1986. Distribution of Zinc and Copper in Typical Alfisols profiles and surface soils of Chittoor district. The Andhra Agricultural Journal. 33:335-342.

Ravankar, H. N., Sujatha Pothare, Rathod, P. K and Sarap, P. A. 2004. Soil properties and yield of sorghum-wheat sequence as affected by longterm fertilization. Indian Journal of Agricultural Research. 38(2): 143- 146.

Sarawad, I.M., Guled, M.B and Gundlur, S.S. 2005. Influence of integrated nutrient supply system for Rabi sorghum chickpea crop rotation on crop yields and soil properties. Karnataka Journal of Agricultural Sciences. 18 (3): 673679.

Selvi, D., Santhy, P and Dhakshinamoorthy. 2003. Efficacy of long-term integrated plant nutrient management on important soil properties of an Inceptisol. Madras Agricultural Journal. 90(10-12): 656660.

Shahid, M., Nayak, A.K., Shukla, A.K., Tripathi, R., Kumar, A., Mohanty, S., Bhattacharyya, P., Raja, R and Panda, B.B. 2013. Long-term effects of fertilizer and manure applications on soil quality and yields in a sub-humid tropical rice-rice system. Soil Use and Management. 29: 322-332.

Sharma, K.L., Balaguravaiah, D., Babu, M.V.S., Reddy, B. R., Srinivasarao,Mishra, P.K., Grace, J.K., Ramesh, G., Madhavi, M., Srinivas, K., Mandal, U.K., Korwar, G.R., Shankar, G.M and Chary, G.R. 2010. Long-Term Impact of Soil and nutrient management practices on soil practices on soil quality in rainfed alfisols at Ananthapur in Andhra Pradesh. Indian Journal of Dryland Agriculture Research \& Development. 25(1): 74-85.

Sharma, K.L., Chandrika, D.S., Grace, J.K., 
Srinivas, K., Mandal, U.K., Raju, B.M. K., Munnalal., Kumar, T.S., Srinivasarao, Reddy, K.S., Osman, M., Indoria, A. K., Usha Rani, K and Kobaku, S.S. 2014. Long-Term Effects of Soil and Nutrient Management Practices on Soil Properties and Additive Soil Quality Indices in SAT Alfisols. Indian Journal of Dryland Agriculture Research \& Development. 29(2): 56-65.

Sharma, S.K., Jain and Upadhyay, B. 2011. Response of groundnut (Arachis hypogaea L.) to balanced fertilization under sub-humid southern plain zone of Rajasthan. Legume Research. 34(4): 273-277.

Sheeba and Kumaraswamy, K. 2001. Influence of continuous cropping and fertilization on physical properties of soil. Madras Agricultural Journal. 88:728 - 732 .

Shirale, S.T., Kide, D.S and Meshram, N.A. 2014. Long-term effect of organic manuring and inorganic fertilizers for enhancing yield and soil properties under Soyabean (Glycine max L.)Safflower (Carthamus tinctorious L.) cropping sequence in vertisol. An Asian Journal of Soil Science. 9(10): 130-136.

Singh, A. K. 2007. Evaluation of soil quality under integrated nutrient management. Journal of the Indian Society Soil Science. 55(1): 58-61.

Singh, A.K., Sarkar, A.K., Kumar, A and Singh, B.P. 2009. Effect of long term use of mineral fertilizers, lime and farm yard manure on the crop yield, available plant nutrient and heavy metal status in an acidic loam soil. Journal of the Indian Society of Soil Science. 57(3): 362-365.

Singh, R.N., Singh, S., Prasad, S.S., Singh, V.K and Pramodkumar. 2011. Effect of integrated nutrient management on soil fertility, nutrient uptake and yield of rice-pea cropping system on an upland acid soil of Jharkhand. Journal of the Indian Society of Soil Science. 59(2): 158- 163.

Srinivasarao, Ch., Venkateswarlu, B., Lal, R., Anil, K.S., Kundu, S., Vittal, K.P.R., Balaguravaiah, G., Shankarbabu, M.V., Chary, G.R., Prasadbabu, M.B.B and Yellamanda, T.R. 2012. Soil carbon sequestration and agronomic productivity of an Alfisol for a groundnut-based system in a semiarid environment in southern India European Journal of Agronomy. 43: 4048.

Srinivasarao, Kundu, S., Venkateswarlu, B., Lal, R., Singh, A.K., Balaguravaiah, G., Vijayasankarbabu, M., Vittal, K.P.R., Reddy, S and Manideep, V.R. 2013. Long-term effects of fertilization and manuring on groundnut yield and nutrient balance of alfisols under rainfed farming in India. Nutrient Cycling Agroecosystem. 96:29-46.

Stalin, P., Ramanathan, S., Nagarajan, R and Natarajan, K. 2006. Long-term Effect of Continous Manurial Practices on Grain yield and Some Soil Chemical Properties in Rice- based Cropping System. Journal of the Indian Society Soil Science. 54(1): 30-37.

Suresh Lal and Mathur, B. S. 1992. Effect of long term application of fertilizers, manure and lime on cationic and anionic status of red loam soil of Ranchi. National Seminar on Development of Soil Science Abstract, 57th Annual Convention. Nov. 26-29, 78-79.

Sutaria, G.S., Akbari, K.N.,Vora, V.D and Padmani, D.R. 2011. Residual effect of management on the soil fertility and yield of black gram under dryland conditions. Legume research. 34(1): 6264.

Tadesse, T., Dechassa, N., Bayu, W., 
Gebeyehu, S. 2013. Effects of farmyard manure and inorganic fertilizer application on soil physicochemical properties and nutrient balance in rainfed lowland rice ecosystem. American Journal of Plant Sciences. 4: 309-316.

Tandon, H. L. S. 1989. Secondary and micronutrients recommendation for soils and crops. A guide book pp. 22.

Tiwari, A., Dwivedi, A.K and Dixit, P.R. 2002. Long-term influence of organic and inorganic fertilization on soil fertility and productivity of soybeanwheat system in vertisol. Journal of the Indian Society of Soil Science. 50(4): $472-475$.

Upadhayay, N.C., Kumar, M., Kaushik, S.K., Khan, M.A and Kumar, M. 2013. Long term effect of nutrient supply options on physical properties of soil in potato based cropping systems. Annals of Horticulture. 6(2): 184-188.

Urkurkar, J.S., Tiwari, A., Chitale, S and Bajpai, R.K. 2010. Influence of longterm use of organic and inorganic manure on soil fertility and sustainable productivity of rice (Oryza sativa) and wheat (Triticum aestivum) in Inceptisols. Indian Journal of Agricultural Sciences. 80(3): 208-212.

Venkatesu, T., Venkaiah, K and Naidu, M. V.
S. 2002. Depth wise distribution of nutrients in groundnut growing soils of Nellore district in Andhra Pradesh. Journal of oilseed Research. 19:185189.

Vennila, R. K and Muthuvel, P. 1998. Effect of long term fertilization on physical properties of soils. Madras Agricultural Journal. 85(5\&6): 290-292.

Verma, A.K.G., Mathur, S.C., Bhandari and Kanthaliya, P.C. 2010. Long term effect of integrated nutrient management on properties of a typic haplustept under maize-wheat cropping system. Journal of the Indian Society of Soil Science. 58(3): 299-302.

Yaduvanshi, N.P.S., Sharma, D.R. and Swarup, A. 2013.Impact of integrated nutrient management on soil properties and yield of rice and wheat in a longterm experiment on a reclaimed sodic Soil. Journal of the Indian Society of Soil Science. 61(3): 188-194.

Yeledhalli, N. A., Prakash, S. S., Ravi, M. V and Narayana Rao, K. 2007. Influence of different levels of Potassium and Calcium on available nutrients, uptake, yield and quality of groundnut in NorthEastern dry zone of Karnataka. Mysore Journal of Agricultural Science. 41 (3): 299-304.

\section{How to cite this article:}

Salma, D., K. Venkaiah and Naidu, M.V.S. 2018. Impact on Soil Properties and Yield of Rainfed Groundnut Mono Cropping System (Arachis hypogae L.) under Long Term Application of Manure and Fertilizers. Int.J.Curr.Microbiol.App.Sci. 7(12): 1346-1360. doi: https://doi.org/10.20546/ijcmas.2018.712.164 